\title{
Exploration on Minority English Teaching from the View of Culture
}

\author{
Ru Wen ${ }^{1}$ \\ ${ }^{1}$ Nanchang Institute of Science \&Technology, Nanchang, Jiangxi, 330000
}

KEYWORDS: English Teaching; Minority Area; Cultural View

\begin{abstract}
Language is a communication tool, but also a cultural view of the world, every nation in the world has its own unique language to reflect their specific cultural identity. So language learning is largely cultural learning, its uniqueness lies in learning the learner may mean new social and cultural patterns of behavior accepted in the acceptance of a new language. As the world's most widely used language, English is almost monopolized the global foreign language education, English teacher in most countries, including China, in the teaching of the target language culture tend to focus on presentation, but generally ignored the culture of the native culture, this single language and cultural teaching model contributed to imperialism and cultural imperialism, led to worldwide extinction or assimilation of some languages, English as the most widely used international language of the world's languages and cultures ecological formation of a growing threat .
\end{abstract}

\section{Situation of Culture Ecology in English Teaching}

China is one of the cultural and educational purposes minority language education, which is aimed at English-speaking countries through cultural learning, promote student of Anglo-American culture of understanding and respect, but also guide the students noted that the cultural differences that exist between different countries. Since 2001, the Ministry of Education began English classes in primary schools nationwide, in addition to the majority of minority students learn their national language and Chinese, but also to learn English. Culture shock in the process of learning English, Chinese and English culture carried by the Anglo-American cultural minority students bring to the inevitable double the Han students, the culture shock will affect minority students of minority culture, Chinese culture and Anglo-American culture recognition and mastery. Therefore, as English learners, most multi-ethnic, national education in China should pay attention to deal with Western culture in English convergence problems of globalization, in order to maintain good foreign language minority cultural and ecological education. From the perspective of cultural ecology of the Frontiers of Yunnan Polytechnic University, a college English teaching cultural review, the existing problems and put forward countermeasures and suggestions in order to maintain good English Culture Ethnic Regions Ecological Environment.

As China joined the WTO, the continuous development of society, the economy has become global integration and cultural exchanges between the peoples of the world become more frequent and more closely, also in a variety of cultural penetration between each other which makes cross-cultural manifestations are also increasingly important in real life. Especially important in the teaching mode of English is very, since our national culture and culture of English-speaking countries in terms of cultural phenomena, customs, habits, there is a difference or conflict, so the ability to develop good cross-cultural communication is very necessary the ability to cross-cultural communication is not simply related to language ability, but there are many aspects, as well as culture-related capabilities, and the ability to target cultural knowledge, attitudes, such as different 
levels of culture. So in the past in the teaching of English, the English teaching focus on language structure, which is a simple word, words, sentences, and other aspects of discourse on language skills, it only for semantic and pragmatic cultural factors specific impact make a single explanation, no education English teaching model from comprehensive language and cultural communication capabilities, such as teaching completely unable to meet under the new situation of economic and cultural exchanges between the peoples of the world needs. In modern social development, how to explore the English Teaching in Ethnic Areas from the "Cross-Cultural Perspective", Students' cross-cultural awareness, promote college students in cross-cultural communicative competence effectively improved to better meet the needs of social development.

\section{Culture Difference in Intercultural Communicative}

In the long history of the category, the unique people of different countries or regions have their own way of life and their way of thinking, so that different cultural backgrounds, often make people different regions have different values, cultural beliefs and customs. In the context of the ideological and cultural beliefs is an important element of culture, different beliefs so that all ethnic groups in weddings, marriage and diet is not the same for each. For Britain, they are the influence of Christianity, they taboo in the diet is not willing to eat with slime and too spicy dishes, avoid MSG seasoning, do not eat dog meat, salt taboo to touch Caesar, even if it is not careful also will feel very depressed, they think it is caused by mouth or with friends a harbinger of diplomatic relations. Personal privacy Westerners value their privacy, particularly with regard to their age, marital status, religious belief and wages of privacy, which is different from the Chinese in terms of age inquiries and inform the Chinese people ask Age expressed concern for each other. Britons also taboo whisper to each other in front of them, and they think this is a rude behavior. Smoking friends met together once remember not point three cigarettes, it will also give three people provoke someone unfortunate. Ethnic customs and beliefs often influence people's behavior and lifestyle awareness. So understanding the various regions in the country's national religion in intercultural communicative use, with full respect for the faith of local residents, they do not violate taboos, in order to better communicate.

English exchange between the West has a lot of cultural differences, such as in the expression language, Chinese people like modesty, humility as China's fine traditional virtues, is the respect and courtesy to others, in exchange for each other in exist view is not been, nor will impose on foreigners who thought, and as Westerners do not like the behavior of modesty, they think often exhibit excessive modesty is hypocritical side. On the language, but also straight to the point, it will not take a roundabout way of speaking, but Watch crucial, then advancing through the layers, in the manner of reasoning put their arguments. And this is different from the language of China, China is exemplified by substantial evidence, and gradually move closer toward the point of view of the way. Therefore, the need to know more about cultural differences, adapt to local thinking outlook orientation conform their mode selected appropriate expression in English teaching should pay attention to cross-cultural learning.

\section{Ethnic Regions English Teaching under Culture View}

China, as an open country, by various cultural impact, whether it is engaged in diplomacy, foreign minister in foreign trade, or do not deal with foreigners, we are conducting cross-cultural communication in today's world-wide cross-cultural communication is carried out, and to become a 
prominent feature of our times, how Minority regions Intercultural Perspective teaching, it will be answered.

In previous English teaching, teachers focus only on students listening, speaking, reading, writing, translation and other aspects of teaching language skills, completely ignoring the Intercultural Communication Ability and English learning cultural differences greatly English students is not conducive to the actual application. Because the language of different cultures caused by differences in customs, ways of thinking and way of communication will affect people's normal exchange or make a contradiction. Teacher education in English, except for some chapters of textbooks and teaching appearing or vocabulary related cultural knowledge, but also the addition of the corresponding teaching materials to explain the English national cultural knowledge, so that teachers and students can truly understand that to want to be fluent in English and communicate with English-speaking people, we must fully understand the cultural background of Western countries, first of all teachers are required to be familiar with the target language and cultural differences between Native cultures, and continuously improve their mastery of a comprehensive system of cultural knowledge, for the purposes of cultural education have an accurate understanding of the requirements on the one hand to grasp the general cultural knowledge, the other is to understand the similarities and differences between specific cultures and different cultures, cannot get the phase impart cultural knowledge and intercultural communicative competence confusion, which is the ability of teachers requirement is even more improved. To really change the "duck" type, "mouthpiece" teaching approach, and implementing modern teaching philosophy to Promote Ethnic English Teaching.

Teachers in teaching an article, not isolated just let the students to understand grammar, recite texts so simple, in ordinary English teaching article content often involves some well-known overseas cities, tourist attractions, historical and cultural aspects. For those unfamiliar famous city, tourist attractions, history and culture students are often lacking, so students have problems understanding of language, often inaccurate. To enable students to these strange things accurately understood cultural objectives are achieved, there can be a better guide to the destination by students to think about learning by means of pictures, maps, multimedia and other aid, to give students the necessary information input knowledge and preparation, so that students from a certain sense of exotic cultures, including local physical presence in the form of culture (such as buildings, environmental characteristics, heritage, etc.), as well as customs and other aspects of experience illustrated. After the further integration of existing cultural knowledge to enable students from a certain depth and breadth of information to tap the cultural geography and culture and other aspects of tourism. Thus virtually guide students to consciously absorb cultural knowledge of English-speaking countries, to digest their cultural differences, to enhance the students' intercultural awareness and intercultural communicative competence, what really makes learning English culture integrated into the teaching mode of language knowledge and skills in learning

Knowledge of the language learning is boring, but the experience of western culture tend to show by an interesting side. Teachers should make full use of various media, the maps, text, sound and in one, such as the world's history, culture, customs, you can use the original English film and television visual material, listening and speaking teaching, the real cross-cultural communicative competence culture integrated into a variety of activities, so that students learn in the entertainment knowledge, knowledge of boring becomes interesting properties, can greatly mobilize the enthusiasm of students; students have created a culture of Intercultural Communicative Competence stage . 


\section{Conclusion}

In English teaching, English culture of the learning process is constantly reflect national culture, and the family culture and the target culture and other cultural process of comparing. Thus, contact of minority cultures and personal experiences carried English culture and language learning can not only stimulate and maintain the enthusiasm of minority students, but also enhance their understanding of their own national culture and reflection, objective understanding of their own values and behavior, in order to cultivate an open, flexible thinking and cross-cultural meaning. For this reason, the teaching of English in minority areas can effectively integrate minority cultural elements in order to maintain a good cultural environment. English Teaching in Ethnic Areas Intercultural Perspective we need joint efforts to overcome cultural differences impede on to train for the social development of modern English talent.

\section{Reference:}

[1] Muhlhausler, P. Language Planning and Language Ecology [J]. Current Issues in Language Planning, 2000, 1 (3).

[2] Phillipson, R. Linguistic Imperialism [M]. Shanghai: Shanghai Foreign Language Teaching Press, 2000.

[3] Cong Fei. "Chinese Culture Aphasia": Defect English Education in China [N]. Guangming Daily 2000, 10, 19.

[4] Jiang Yi. College English teaching cannot be ignored in a two-way cultural exchange [J]. Jiangsu Foreign Language Teaching and Research, 2005 (2).

[5] Li Yuming. Chinese English programming theory [M]. Changchun: Northeast Normal University Press, 2005. 